\title{
PENGEMBANGAN PERANGKAT PEMBELAJARAN IPA BERBASIS KURIKULUM 2013 UNTUK MELATIH LITERASI SAINS SISWA SMP
}

\author{
Inzanah ${ }^{1}$ \\ Muslimin Ibrahim ${ }^{2}$ \\ Wahono Widodo ${ }^{2}$ \\ ${ }^{1}$ Program Studi Pendidikan Sains, Program Pascasarjana, Universitas Negeri Surabaya \\ ${ }^{2}$ Dosen Program Studi Pendidikan Sains, Program Pascasarjana, Universitas Negeri Surabaya \\ e-mail: iin.scientist@gmail.com
}

\begin{abstract}
The purposes of this study are to develop science learning material based on Curriculum 2013 to try science literacy of students in junior high school and then describe it. The learning material is developed by adapting Dick and Carey development model and the research design is One Group Pretest-Posttest Design. Try out of this research uses sample that are consist of 21 students with 2 observers and 2 validators. Research findings showed that component of learning material that are developed are valid, 80\% score in readability and 10,6\% score in difficulty. The learning material is practical in learning process. Average score of all activities in learning implementation is 3,6 with very good category. The learning material is also effective to try skill of student's science literacy until 4th levels. Students involve in learning process actively and give positive response in those learning. The conclusion of this research is science learning material based on curriculum 2013 in fluids pressure and it application in daily life matter can be used to try science literacy of students in class VIII Junior High School properly.
\end{abstract}

Keywords: Learnin Material, Curriculum 2013, and Science Literacy.

\begin{abstract}
Abstrak: Penelitian ini bertujuan untuk mengembangkan perangkat pembelajaran IPA berbasis Kurikulum 2013 untuk melatih literasi sains siswa SMP dan kemudian mendeskripsikannya. Perangkat dikembangkan dengan mengadaptasi model pengembangan Dick and Carey, sedangkan rancangan uji coba yang digunakan adalah One Group Pretest-Posttest Design. Penelitian uji coba ini menggunakan sampel 21 siswa dengan 2 orang pengamat serta 2 validator. Temuan hasil penelitian menunjukkan bahwa komponen perangkat pembelajaran yang dikembangkan adalah valid, memiliki tingkat keterbacaan sebesar 80\% dan tingkat kesulitan yang rendah yaitu 10,6\%. Perangkat pembelajaran yang dihasilkan praktis digunakan dalam pembelajaran yang terlihat dari tingginya skor rata-rata kesuluruhan keterlaksanaan pembelajaran adalah 3,6 dengan kategori sangat baik. Perangkat pembelajaran yang dikembangkan juga efektif untuk melatih kemampuan literasi sains siswa sampai pada level 4. Begitu pula dengan aktivitas siswa yang dominan aktif dalam pembelajaran, siswa juga memberikan respon positif terhadap kegiatan pembelajaran. Berdasarkan hasil penelitian uji coba ini, dapat disimpulkan bahwa perangkat pembelajaran IPA berbasis Kurikulum 2013 materi tekanan zat cair dan penerapannya dalam kehidupan sehari-hari layak digunakan untuk melatih literasi sains siswa SMP kelas VIII.
\end{abstract}

Kata Kunci: Perangkat Pembelajaran, Kurikulum 2013, dan Literasi Sains Siswa.

\section{PENDAHULUAN}

Ilmu Pengetahuan Alam (IPA) merupakan ilmu yang berkaitan dengan upaya memahami berbagai fenomena alam secara sistematis. Sehingga, pembelajaran IPA bukan hanya menekankan pada penguasaan sejumlah pengetahuan sebagai produk, tetapi juga harus menyediakan ruang yang cukup untuk tumbuh kembangnya sikap ilmiah, berlatih melakukan penyelesaian masalah, dan mengaplikasikannya dalam kehidupan nyata (Subali dkk, 2009: 1).

Tantangan abad 21 ditandai oleh pesatnya perkembangan teknologi yang diterapkan dalam berbagai bidang kehidupan di masyarakat. Oleh karena itu, diperlukan cara pembelajaran yang dapat menyiapkan peserta didik yang memiliki literasi terhadap IPA dan teknologi, serta mampu berpikir secara komprehensif dalam menyelesaikan berbagai persoalan dalam kehidupan nyata. Oleh karena itu, siswa dituntut menguasai IPA secara terpadu (Subali dkk, 2009: 1).
Pengukuran literasi sains tidak hanya penting untuk mengetahui sejauh mana pemahaman peserta didik terhadap pengetahuan sains, tetapi juga pemahaman terhadap berbagai aspek proses sains, serta kemampuan mengaplikasikan pengetahuan dan proses sains dalam situasi nyata.

Berdasarkan data PISA tahun 2013 yang publikasikan oleh Organization For Economic Cooperation and development (OECD) menunjukkan bahwa tingkat literasi sains siswa Indonesia masih rendah dan di bawah rata-rata OECD. Adapun skor rata-rata literasi sains diperoleh adalah 382 dengan skor rata-rata OECD adalah 501 (OECD, 2013: 5). Berdasarkan data Progress in International Reading Literacy Study (PIRLS) yang diterbitkan oleh National Center Education Statistics (NCES) tahun 2011 skor literasi membaca siswa Indonesia adalah 428. Sedangkan skor literasi pengalaman pada tahun 2011 adalah 418 dan kemampuan untuk memperoleh dan menggunakan 
informasi 439 dengan skor rata-rata dari PIRLS adalah 500 untuk semua kategori (NCES, 2012: 8).

Berdasarkan hasil penelitian pada uji coba I yang dilakukan di SMP Muhammadiyah 5 Pucang Surabaya, diketahui bahwa perangkat pembelajaran yang dikembangkan layak digunakan untuk melatih kemampuan literasi sains siswa sampai pada level 3 (Inzanah, 2014: 132). Rendahnya literasi sains bangsa Indonesia terindikasi dalam banyak hal, misalnya seseorang merasa aman berteduh di bawah pohon rindang ketika hujan berpetir, seseorang membawa skala thermometer di dekat kipas angina dan masih banyak bukti-bukti lain yang dapat menjadi indikator rendahnya literasi sains di Indonesia. Meskipun beberapa siswa Indonesia mampu mendapatkan nilai yang tinggi dalam ujian nasional ataupun mampu menjuarai olimpiade sains, akan tetapi prestasi tersebut belum menjamin bahwa Indonesia dapat dikatakan sebagai negara yang literat terhadap sains.

Salah satu materi di SMP yang memuat kontekskonteks yang sesuai dengan domain konten dalam literasi sains adalah materi Tekanan Zat Cair dan Penerapannya dalam Kehidupan Sehari-hari. Adapun konteks yang dapat dijabarkan dari materi tersebut adalah meliputi kesehatan, sumber daya alam, lingkungan, bahaya, serta aplikasi sains dan teknologi dengan relevansinya terhadap kehidupan personal, sosial, maupun global.

Pokok bahasan Tekanan Zat Cair dan Penerapannya dalam Kehidupan Sehari-hari merupakan salah satu pokok bahasan di SMP kelas VIII semester Genap. Pengetahuan dan pemahaman terkait konsepkonsep tersebut dapat diperoleh siswa melalui kegiatan penyelidikan atau pengamatan dengan bimbingan guru. Memperhatikan alasan tersebut di atas, diperlukan metode pembelajaran yang mampu memfasilitasi siswa untuk dapat menguasai konsep-konsep tersebut dan sesuai dengan tuntutan Kurikulum 2013.

Salah satu metode yang sesuai dengan materi Tekanan Zat Cair dan Penerapannya dalam Kehidupan Sehari-hari dan tuntutan Kurikulum 2013 adalah metode pembelajaran dengan penemuan (guided discovery) yang merupakan suatu metode pembelajaran yang menekankan pada pendekatan sains dan dapat digunakan untuk mengajarkan konsep serta keterampilan melalui proses penemuan.

Kurikulum 2013 telah dinyatakan berlaku di Indonesia secara bertahap. Banyak faktor yang diperlukan untuk mendukung keberhasilan pelaksanaan kurikulum tersebut, salah satu faktor pentingnya adalah ketersediaan perangkat pembelajaran yang sesuai dengan Kurikulum 2013. Berdasarkan pemikiran latar belakang yang terkait dengan fakta tentang rendahnya literasi siswa Indonesia dan belum terpenuhinya perangkat pembelajaran yang sesuai dengan kurikulum yang diberlakukan oleh pemerintah saat ini, maka peneliti mengambil judul Pengembangan Perangkat Pembelajaran IPA Berbasis Kurikulum 2013 untuk Melatih Literasi Sains Siswa SMP.

Berdasarkan uraian latar belakang, secara umum dapat dirumuskan pertanyaan penelitian yaitu: bagaimanakah kelayakan perangkat pembelajaran IPA berbasis Kurikulum 2013 untuk melatih literasi sains siswa SMP?. Menjawab pertanyaan pokok tersebut, dapat dijawab terlebih dahulu pertanyaan-pertanyaan sebagai berikut: (1) bagaimana validitas perangkat pembelajaran yang dikembangkan?; (2) bagaimana tingkat keterbacaan buku siswa yang dikembangkan?; (3) Bagaimana tingkat kesulitan materi buku siswa yang dikembangkan?; (4) bagaimana keterlaksanaan pembelajaran dengan menggunakan perangkat pembelajaran yang dikembangkan?; (5) bagaimana aktivitas siswa selama pelaksanaan pembelajaran dengan menggunakan perangkat pembelajaran yang dikembangkan? (6) bagaimana literasi sains siswa setelah melngikuti pembelajaran dengan perangkat pembelajaran yang dikembangkan? (7) bagaimana respon siswa terhadap pembelajaran berbasis perangkat yang dikembangkan? Adapun tujuan dari penelitian ini adalah untuk mengembangkan perangkat pembelajaran IPA berbasis Kurikulum 2013 untuk melatih literasi sains siswa SMP dan kemudian mendeskripsikannya.

Kurikulum 2013 menekankan bahwa pembelajaran IPA adalah pembelajaran berbasis integrated science (IPA terpadu) bukan sebagai pendidikan disiplin ilmu. Hal tersebut bermakna bahwa IPA merupakan pendidikan berorientasi aplikatif, pengembangan kemampuan berpikir, kemampuan belajar, rasa ingin tahu, dan pengembangan sikap peduli dan bertanggung jawab terhadap lingkungan sosial dan alam (Kemendikbud, 2013: 6)

Proyek 2061: Science for all Americans menyatakan bahwa sekolah dan guru tidak membutuhkan konten dan pengajaran yang banyak, tetapi fokus kepada makna esensial dari literasi sains sehingga mampu mengajarkan suatu konsep secara efektif. Kurikulum sains terpadu merupakan kurikulum yang menghubungkan konten yang berbeda dari ilmu pengetahuan, teknologi, dan matematika. Hal ini diperlukan untuk meningkatkan literasi sains pada siswa. Dengan membuat hubungan antara konten ilmu pengetahuan, teknologi, dan matematika serta dengan melibatkan siswa dalam kegiatan ilmu pengetahuan di dunia nyata, siswa dapat mulai mengembangkan keterampilan dan proses yang diperlukan untuk benarbenar memiliki literasi sains (Turpin dan Cage, 2004: 1314).

Sains yang didasarkan pada penemuan, melibatkan siswa dalam menggunakan ilmu pengetahuan sebagai alat untuk menjawab pertanyaan tentang fenomena dunia nyata. Pembelajaran melalui penemuan dan literasi saling berpotongan ketika siswa menggunakan ketrampilan membaca, menulis, dan bahasa lisan untuk menjawab pertanyaan tentang isi sains (misalnya, mengapa manusia dapat melihat warna yang berbeda), dan membangun kapasitas mereka untuk terlibat dalam penalaran ilmiah (misalnya, bagaimana untuk mengumpulkan data dalam cara yang terkontrol) (Hapgood dan Palincsar, 2006: 56).

\section{METODE}

Penelitian ini merupakan penelitian pengembangan, yaitu pengembangan perangkat pembelajaran IPA berbasis Kurikulum 2013 untuk 
melatih literasi sains siswa SMP. Penelitian ini dikembangkan dengan mengadaptasi pada model pengembangan Dick and Carey. Rancangan uji coba yang digunakan adalah One Group Pretest-Posttest Design

Subjek dalam penelitian ini adalah perangkat pembelajaran IPA berbasis Kurikulum 2013 untuk melatih literasi sains siswa SMP yang diujicobakan secara terbatas pada10 siswa yang dipilih secara acak dari kelas VIII-H SMP Muhammadiyah 5 Pucang Surabaya dan diimplemetasikan di kelas sebenarnya melibatkan 21 siswa kelas VIII SMP Raudlatul Jannah tahun pelajaran $2013 / 2014$.

Instrumen penelitian yang digunakan meliputi: lembar validasi perangkat pembelajaran, lembar tingkat keterbacaan dan kesulitan buku siswa, lembar pengamatan keterlaksanaan pembelajaran, lembar pengamatan aktivitas siswa, tes literasi sains siswa, dan angket respon siswa. Teknik pengumpulan data yang digunakan dalam penelitin ini meliputi dokumentasi, observasi, pemberian angket, dan pemberian tes. Teknik analisis data yang digunakan meliputi deskripsi kualitatif untuk mendeskripsikan validitas perangkat pembelajaran. Deskripsi persentase untuk mendeskripsikan tingkat keterbacaan, tingkat kesulitan, aktivitas siswa, dan respon siswa. Deskripsi kuantitatif untuk mendeskripsikan keterlaksanaan pembelajaran dan kemampuan literasi sains siswa.

\section{HASIL DAN PEMBAHASAN}

Perangkat yang dikembangkan sudah pernah diimplementasikan pada uji coba I di SMP Muhammadiyah 5 Pucang Surabaya. Setelah dilakukan perbaikan sesuai saran dari para pakar, perangkat tersebut diimplementasikan di SMP Raudlatul Jannah. SMP Muhammadiyah 5 Pucang Surabaya dan SMP Raudlatul Jannah adalah SMP swasta dengan karakteristik siswa yang tidak jauh berbeda, khusunya pada subyek penelitian yaitu siswa kelas VIII yang umumnya berusia antara 12-15 tahun. Begitu pula dengan kurikulum yang digunakan yaitu masih menggunakan Kurikulum Tingkat Satuan Pendidikan (KTSP). Selain itu, dari hasil pretes diketahui bahwa level literasi sains di kedua SMP tersebut berada pada level 2, hal ini menunjukkan bahwa kemampuan literasi sains awal yang dimiliki oleh siswa adalah sama.

Perangkat pembelajaran yang dikembangkan dalam penelitian ini berupa perangkat pembelajaran IPA berbasis kurikulum 2013 untuk melatih literasi sains siswa SMP. Perangkat tersebut merupakan produk dari pengembangan yang dilakukan, yang terdiri dari RPP, buku siswa, LKS, dan tes literasi sains. Untuk mengetahui validitas perangkat pembelajaran yang dikembangkan, dilakukan validasi ke para pakar. Hasil validasi perangkat pembelajaran disajikan dalam Tabel 1.
Tabel 1 Hasil Validasi Perangkat Pembelajaran

\begin{tabular}{|c|c|c|c|}
\hline Perangkat & $\begin{array}{c}\text { Rata-rata } \\
\text { Skor/nilai } \\
\text { Validasi } \\
\end{array}$ & $\begin{array}{l}\text { Relia- } \\
\text { bilitas }\end{array}$ & Keterangan \\
\hline $\begin{array}{l}\text { Rencana Pelaksanaan } \\
\text { Pembelajaran (RPP) }\end{array}$ & 3 & 1,0 & \multirow{3}{*}{$\begin{array}{c}\text { Dapat } \\
\text { digunakan } \\
\text { dengan revisi } \\
\text { kecil }\end{array}$} \\
\hline Buku Siswa & 4 & 1,0 & \\
\hline $\begin{array}{l}\text { Lembar Kegiatan } \\
\text { Siswa (LKS) }\end{array}$ & 3,3 & 0,9 & \\
\hline Tes Literasi Sains & $\mathrm{B}$ dan $\mathrm{A}$ & & $\begin{array}{c}\text { Valid dengan } \\
\text { revisi }\end{array}$ \\
\hline
\end{tabular}
menunjukkan bahwa skor yang diperoleh dari setiap komponen RPP adalah 3 dengan reliabilitas 1,0. Adapun nilai RPP yang diperoleh dari total seluruh skor tersebut dengan menggunakan formulasi yang telah ditentukan adalah 100 dengan kategori sangat baik (A). Hal ini menunjukkan bahwa RPP dapat digunakan dalam kegiatan pembelajaran.

Buku siswa yang diimplementasikan dalam penelitian ini, merupakan buku siswa yang disusun dengan mengacu pada BSNP dan menggunakan kurikulum 2013. Tabel 1 menunjukkan rata-rata skor penilaian buku siswa dari dua validator. Skor validasi untuk setiap komponen buku siswa adalah 4 dengan kategori sangat baik. Dari skor validasi tersebut menunjukkan bahwa buku siswa layak digunakan dalam kegiatan pembelajaran.

Hasil validasi lembar kegiatan siswa (LKS) pada Tabel 1 menunjukkan skor rata-rata dari dua validator untuk seluruh aspek penilaian adalah 3,3 dengan kategori baik. Tes literasi sains yang dikembangkan terdiri dari 20 butir soal, dengan rincian 5 soal untuk level 1; 5 soal untuk level 2; 3 soal untuk level 3; 3 soal untuk level 4; 3 soal untuk level 5; dan 1 soal untuk level 6

Penilaian validator dalam setiap kategori kelayakan RPP, buku siswa, LKS, dan tes literasi sains adalah berkategori baik dan sangat baik, sehingga semua perangkat pembelajaran yang dikembangkan layak digunakan dalam kegiatan pembelajaran.

\section{Tingkat Keterbacaan dan Kesulitan Buku Siswa}

Tingkat keterbacaan buku siswa dievaluasi berdasarkan close procedure. Persentase tingkat keterbacaan dan kesulitan buku siswa ditunjukkan dalam Tabel 2.

Tabel 2 Tingkat Keterbacaan dan Kesulitan Buku Siswa

\begin{tabular}{|l|c|}
\hline \multicolumn{1}{|c|}{ Aspek } & $\begin{array}{c}\text { Rata-rata } \\
\text { Persentase }\end{array}$ \\
\hline Tingkat keterbacaan buku siswa & 80 \\
\hline Tingkat kesulitan buku siswa sub kajian I & 11,5 \\
\hline Tingkat kesulitan buku siswa sub kajian II & 9,4 \\
\hline Tingkat kesulitan buku siswa sub kajian III & 10,8 \\
\hline
\end{tabular}

Tabel 2 memuat informasi terkait persentase tingkat keterbacaan buku siswa. Berdasarkan rata-rata persentase yang diperoleh, diketahui bahwa persentase tingkat keterbacaan pada tahap implementasi sebesar $80 \%$. Menurut Sitepu (2010), apabila persentase tingkat keterbacaan buku siswa $>50 \%$, menunjukkan bahwa buku 
siswa mudah untuk dipahami dan siswa dapat mengerti isi bacaan.

Ide penting yang dipaparkan Vygotsky adalah konsep scaffolding atau mediated learning atau dukungan tahap demi tahap belajar dan pemecahan masalah, yaitu dengan memberikan sejumlah bantuan kepada siswa pada awal tahap pembelajaran, kemudian menguranginya dan memberikan kesempatan kepada siswa untuk mengambil alih tanggung jawab sekadar yang mereka mampu (Nur, 2008: 6). Dalam mengisi kata-kata yang dikosongkan dalam tes tingkat keterbacaan buku siswa, siswa diberikan bantuan, sehingga mampu mengikuti tahap dan melengkapi kata-kata yang dikosongkan tersebut dengan baik.

Tabel 2 juga memberikan informasi terkait persentase tingkat kesulitan materi buku siswa. Tingkat kesulitan yang dialami siswa dalam memahami materi dalam buku siswa terlihat dari banyaknya jumlah kalimat yang kurang dipahami siswa melalui metode menggarisbawahi. Dari tabel tersebut, nampak bahwa tingkat persentase kesulitan materi buku siswa dari sub kajian I sampai sub kajian III secara berurutan adalah $11,1 \% ; 9,3 \% ; 10,4 \%$. Hal tersebut menunjukkan bahwa persentase kesulitan materi buku siswa $<40 \%$ yang bermakna bahwa buku siswa mudah dipahami.

\section{Keterlaksanaan Pembelajaran}

Keterlaksanaan RPP selama proses pengambilan data diamati oleh dua orang pengamat dari sekolah yang bersangkutan. Hasil pengamatan didokumentasikan dalam lembar pengamatan keterlaksanaan RPP. Hasil pengamatan dan reabilitas dapat dilihat dalam Tabel 3.

Tabel 3 Keterlaksanaan Pembelajaran

\begin{tabular}{|c|c|c|c|c|}
\hline No. & Aspek yang Diamati & $\begin{array}{c}\text { Skor } \\
\text { Rata-rata }\end{array}$ & $\begin{array}{l}\text { Relia- } \\
\text { bilitas }\end{array}$ & Kategori \\
\hline 1. & $\begin{array}{l}\text { Fase 1: } \\
\text { Mengorientasikan } \\
\text { Sisiwa pada Masalah. }\end{array}$ & 3,7 & \multirow{6}{*}{0,99} & $\begin{array}{l}\text { Sangat } \\
\text { Baik }\end{array}$ \\
\hline 2. & $\begin{array}{l}\text { Fase 2: Mengorganisasi } \\
\text { Siswa untuk Belajar dan } \\
\text { Melakukan Kegiatan } \\
\text { Penemuan. }\end{array}$ & 3,6 & & $\begin{array}{l}\text { Sangat } \\
\text { Baik }\end{array}$ \\
\hline 3. & $\begin{array}{l}\text { Fase 3: Membimbing } \\
\text { Kegiatan Penyelidikan } \\
\text { atau Penemuan Secara } \\
\text { Individu maupun } \\
\text { Kelompok. }\end{array}$ & 3,7 & & $\begin{array}{l}\text { Sangat } \\
\text { Baik }\end{array}$ \\
\hline 4. & $\begin{array}{l}\text { Fase 4: } \\
\text { Mengembangkan dan } \\
\text { Menyajikan Hasil Karya } \\
\text { serta Mempresentasikan } \\
\text { Hasil Kegiatan. }\end{array}$ & 3,7 & & $\begin{array}{l}\text { Sangat } \\
\text { Baik }\end{array}$ \\
\hline 5. & $\begin{array}{l}\text { Fase 5: Menganalisis } \\
\text { dan Mengevaluasi } \\
\text { Proses Penemuan. }\end{array}$ & 3.5 & & Baik \\
\hline 6. & Penutup & 3,5 & & Baik \\
\hline \multicolumn{2}{|c|}{ Rata-rata Keseluruhan } & 3,6 & 0,9 & $\begin{array}{c}\text { Sangat } \\
\text { Baik }\end{array}$ \\
\hline
\end{tabular}

pembelajaran berdasarkan Tabel 3 menunjukkan bahwa rata-rata keseluruhan kemampuan guru dalam mengelola kegiatan pembelajaran berkategori sangat baik. Total rata-rata keterlaksanaan pembelajaran yang diperoleh adalah 3,6 dengan kategori sangat baik. Hal ini dapat terjadi karena siswa termotivasi untuk menggali informasi-informasi baru serta mengolah informasiinformasi yang mereka dapatkan dengan informasiinformasi yang telah dimiliki sebelumnya melalui penjelasan guru, sumber belajar yang digunakan, serta kegiatan penemuan yang dilakukan dalam pembelajaran.

Besarnya reliabilitas instrumen pengamatan keterlaksanaan perangkat pembelajaran yakni 0,9. Dengan demikian, dapat dikatakan bahwa reliabilitas keterlaksanaan pembelajaran $>0,75$. Menurut Borich (1994), instrumen dikategorikan baik dan dapat digunakan dalam kegiatan pengamatan apabila memiliki realiabilitas di atas 0,75 atau $75 \%$. Sehingga, pengelolaan pembelajaran dengan menggunakan perangkat pembelajaran IPA berbasis Kurikulum 2013 berlangsung dengan baik.

Piaget (1886-1980) menjelaskan bahwa secara alamiah setiap anak memiliki rasa ingin dan berusaha secara terus menerus memahami dunia sekitarnya. Menurut Piaget, siswa dalam segala usia secara aktif terlibat dalam proses perolehan informasi dan membangun informasi yang diperoleh di dalam diri mereka sendiri. Pengetahuan secara terus menerus tumbuh dan berubah pada saat siswa menghadapi pengalaman-pengalaman baru yang memaksa mereka membangun dan memodifikasi pengetahuan awal mereka.

\section{Aktivitas Siswa}

Pengamatan aktivitas siswa dilakukan oleh dua pengamat dalam setiap pertemuan. Data hasil pengamatan aktivitas siswa dipaparkan pada Gambar 1 .

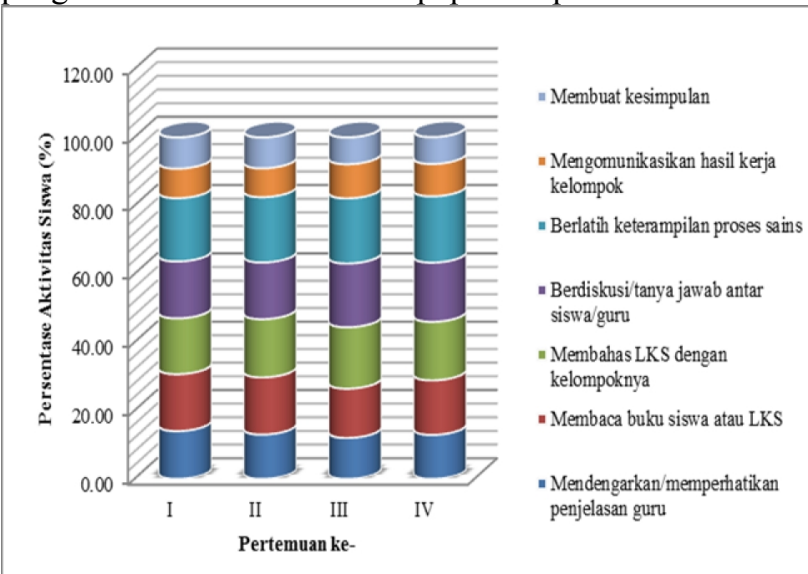

Gambar 1 Diagram Aktivitas Siswa dalam Pembelajaran

Aktivitas siswa dalam pembelajaran yang digambarkan dalam diagram batang pada Gambar 1, menunjukkan bahwa persentase aktivitas dominan yang dilakukan siswa adalah berlatih keterampilan proses sains dengan persentase rata-rata 19,04\%. Dalam lembar pengamatan aktivitas siswa, nampak bahwa siswa aktif dalam kegiatan pembelajaran. Hal ini ditunjukkan oleh tingginya persentase kegiatan diskusi yang dilakukan antar siswa/guru dengan persentase sebesar 17,34\%. Selain itu, siswa juga aktif dalam membahas LKS dengan kelompoknya serta membaca buku siswa/LKS dengan masing-masing persentasenya adalah $17,13 \%$ dan 15,97\%. Analisis data pada Gambar 1 menunjukkan bahwa rata-rata reliabilitas dari kegiatan pembelajaran 
dengan menggunakan perangkat yang dikembangkan adalah sebesar 0,95. Menurut Borich (1994), instrumen dikategorikan baik dapat digunakan dalam kegiatan pengamatan apabila memiliki reliabilitas $>0,75$ atau $>$ $75 \%$. Dengan demikian instrument pengamatan aktivitas siswa berada dalam kategori baik.

Berdasarkan pemaparan di atas, terlihat bahwa aktivitas siswa selama kegiatan pembelajaran adalah sesuai dengan tahap-tahap metode guided discovery. Keterlaksanaan metode guided discovery sebagaimana tertuang dalam RPP tentu akan meningkatkan aktivitas siswa dalam pembelajaran. Hal ini sesuai dengan pernyataan Piaget dan Bruner (dalam Charin, 1993) yang menyatakan bahwa pendekatan guided discovery menekankan pada penemuan seseorang yang memiliki kesempatan dalam membangun pengetahuannya sendiri, sehingga potensi intelektual siswa akan meningkat.

Dari pernyataan tersebut, jelas bahwa apabila persentase keterlaksanaan pembelajaran dengan metode guided discovery tinggi, maka aktivitas siswa dalam pembelajaran tersebut juga meningkat. Hal ini dikarenakan, dalam pembelajaran dengan metode guided discovery siswa terlibat aktif dalam menemukan konsep/prinsip sains melalui kegiatan penemuan yang kemudian diaplikasikan dalam menyelesaikan masalahmasalah yang diberikan oleh guru.

Hasil pengamatan aktivitas siswa dalam kegiatan pembelajaran memiliki kesamaan hasil dengan penelitian yang dilakukan oleh Fathur Rohim, dkk yang melaporkan bahwa pembelajaran dengan metode discovery terbimbing mampu meningkatkan aktivitas dan hasil belajar siswa apabila dibandingkan dengan metode diskusi (Fathur Rohim, dkk, 2012). Hal ini juga didukung oleh hasil penelitian Akinbola (2009) menyatakan bahwa pembelajaran guided discovery dapat membuat siswa melakukan pemecahan masalah, belajar mandiri, berpikir kritis, kreatif dan bukan menghafal.

\section{Kemampuan Literasi Sains Siswa}

Kemampuan literasi sains yang dimaksud adalah hasil tes kemampuan literasi sains siswa dengan indikator pencapaian yang dikembangkan dari indikator pembelajaran dan disesuaikan dengan indikator PISA 2013. Hasil tes direpresentasikan dalam bentuk skoring dan leveling. Analisis yang dilakukan meliputi analisis data pretes dan postes yang kemudian dihitung N-Gain skornya untuk mengetahui peningkatan skor antara sebelum dan sesudah kegiatan pembelajaran.

Kemampuan literasi sains yang diukur meliputi penguasaan domain pengetahuan, konteks, kompetensi, dan sikap sains yang dimiliki siswa. Data hasil tes literasi sains siswa yang meliputi penguasaan domain pengetahuan, konteks, dan kompetensi dapat dilihat dalam Tabel 4.

Tabel 4 Hasil Tes Literasi Sains Siswa

\begin{tabular}{|c|c|c|c|c|c|c|c|}
\hline \multirow{2}{*}{$\begin{array}{c}\text { Kode } \\
\text { Siswa }\end{array}$} & \multicolumn{2}{|c|}{ Nilai } & \multirow{2}{*}{ U2-U1 } & $\begin{array}{c}\text { N- } \\
\text { Gain }\end{array}$ & Kategori & \multicolumn{2}{|c|}{$\begin{array}{c}\text { Level } \\
\text { Literasi } \\
\text { Sains }\end{array}$} \\
\cline { 2 - 5 } & U1 & U2 & & & & U1 & U2 \\
\hline ZMR & 37 & 65 & 28 & 0.4 & Sedang & 2 & 4 \\
\hline FRK & 22 & 48 & 26 & 0.3 & Sedang & 2 & 3 \\
\hline
\end{tabular}

\begin{tabular}{|c|c|c|c|c|c|c|c|}
\hline MFBS & 44 & 63 & 19 & 0.3 & Sedang & 3 & 4 \\
\hline WJF & 27 & 48 & 21 & 0.3 & Sedang & 2 & 3 \\
\hline TPP & 5 & 44 & 39 & 0.4 & Sedang & 1 & 3 \\
\hline NIA & 41 & 56 & 15 & 0.3 & Sedang & 3 & 4 \\
\hline MIP & 31 & 51 & 20 & 0.3 & Sedang & 2 & 3 \\
\hline ASU & 52 & 80 & 28 & 0.6 & Sedang & 3 & 5 \\
\hline MF & 32 & 71 & 39 & 0.6 & Sedang & 2 & 4 \\
\hline SSI & 38 & 67 & 29 & 0.5 & Sedang & 2 & 4 \\
\hline GAA & 32 & 62 & 30 & 0.4 & Sedang & 2 & 4 \\
\hline STHB & 27 & 61 & 34 & 0.5 & Sedang & 2 & 4 \\
\hline AY & 39 & 61 & 22 & 0.4 & Sedang & 2 & 4 \\
\hline MARA & 35 & 55 & 20 & 0.3 & Sedang & 2 & 3 \\
\hline AIH & 33 & 51 & 18 & 0.3 & Sedang & 2 & 3 \\
\hline SS & 43 & 62 & 19 & 0.3 & Sedang & 3 & 4 \\
\hline DRA & 35 & 62 & 27 & 0.4 & Sedang & 2 & 4 \\
\hline TFA & 30 & 59 & 29 & 0.4 & Sedang & 2 & 4 \\
\hline SFO & 22 & 46 & 24 & 0.3 & Sedang & 2 & 3 \\
\hline AHM & 26 & 54 & 28 & 0.4 & Sedang & 2 & 3 \\
\hline MA & 30 & 49 & 19 & 0.3 & Sedang & 2 & 3 \\
\hline Total & $\mathbf{3 2}$ & $\mathbf{5 8}$ & $\mathbf{2 6}$ & $\mathbf{0 . 4}$ & Sedang & $\mathbf{2}$ & $\mathbf{4}$ \\
\hline
\end{tabular}

Hasil tes literasi sains siswa khususnya pada domain pengetahuan, konteks, dan kompetensi yang terdapat pada Tabel 4, menyatakan bahwa setelah kegiatan pembelajaran dengan menggunakan perangkat pembelajaran IPA berbasis Kurikulum 2013 dengan metode guided discovery, terdapat peningkatan skor dan level literasi sains siswa.

Pada kegiatan pretes, skor rata-rata yang diperoleh siswa adalah 32 dan berada pada level 2. Dalam kegiatan postes, skor dan level literasi sains siswa meningkat. Skor rata-rata yang diperoleh siswa setelah kegiatan pembelajaran adalah 58 dan level literasi sains siswa meningkat menjadi level 4. Dalam (OECD, 2013: 113), dinyatakan bahwa pada level 4 siswa memiliki kemampuan dalam bekerja secara efektif dengan situasi dan masalah yang mungkin melibatkan fenomena eksplisit, sehingga mengharuskan mereka untuk membuat kesimpulan tentang peran pengetahuan sains ataupun teknologi, memilih dan memadukan keterangan dari berbagai disiplin sains atau teknologi yang berbeda dan penghubung keterangan tersebut secara langsung ke dalam aspek dari situasi kehidupan, mencerminkan aksi dan dapat mengomunikasikan dengan menggunakan pengetahuan sains, keputusan, dan fakta.

Skor rata-rata literasi sains siswa Indonesia dalam PISA 2013 (OECD, 2013: 5) adalah 382 dengan skor rata-rata OECD adalah 501. Apabila skor tersebut dikonversikan ke dalam skala level, maka kemampuan literasi sains siswa Indonesia adalah berada pada level 1. Pada level 1, siswa memiliki pengetahuan sains terbatas yang hanya dapat diaplikasikan pada beberapa keadaan yang familiar dengan siswa dan siswa mampu menggunakan penjelasan ilmiah/sains dengan jelas maupun secara eksplisit dari petunjuk yang diberikan. 
Dalam data PISA 2013 dapat diketahui bahwa level tertinggi yang mampu dicapai siswa Indonesia adalah pada level 4 , akan tetapi dengan persentase yang sangat sedikit.

Hasil pengukuran PISA 2013 (OECD 2013: 232), menyatakan bahwa level literasi sains siswa Indonesia berada pada peringkat ke dua dari level terendah PISA setelah Peru. Berikut ini adalah perbandingan pencapaian level literasi sains siswa dalam PISA, siswa kelas VIII-H SMP Muhammadiyah 5 Pucang Surabaya, dan siswa kelas VIII SMP Raudlatul Jannah.

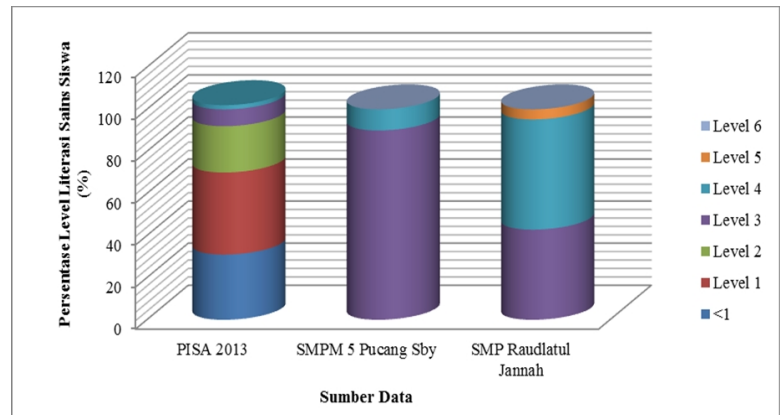

Gambar 2 Perbandingan Persentase Pencapaian Level Literasi Sains

PISA 2013 (OECD, 2013: 5) menyatakan bahwa $31 \%$ siswa Indonesia berada pada below level 1 (di bawah level 1) yang menunjukkan bahwa siswa tidak berhasil mengerjakan soal-soal dasar dalam pengukuran PISA. Misalnya, siswa mengalami kesulitan dalam menggunakan manfaat dari ilmu pengetahuan, pembelajaran, dan berpartisipasi dalam situasi kehidupan yang berkaitan dengan perkembangan ilmu pengetahuan dan teknologi (OECD, 2013:5). Selanjutnya 39\% berada pada level 1 dan $22 \%$ berada pada level 2. Sedangkan siswa yang mampu mencapai level 3 hanya sebesar $8 \%$ dan hanya $2 \%$ yang mampu mencapai level 3 ke atas.

Level literasi sains siswa Indonesia berada pada peringkat ke dua dari level terendah PISA setelah Peru. Hasil literasi sains yang dipublikasikan PISA mengungkapkan gambaran literasi siswa secara menyeluruh untuk rata-rata siswa indonesia. Hasil literasi sains dapat berbeda apabila dilakukan tes pada ruang lingkup yang lebih kecil. Apalagi mengingat potensi, karakteristik daerah, sosial budaya masyarakat, dan peserta didik Indonesia yang beragam, tentu juga akan memberikan pengaruh kepada aspek-aspek belajar yang temasuk juga kemampuan literasi sains.

Gambar 2 memberikan informasi terkait perbandingan antara persentase pencapaian level literasi sains siswa Indonesia dalam PISA 2013 dengan pencapaian level literasi sains siswa kelas VIII-H SMP Muhammadiyah 5 Pucang Surabaya dan siswa kelas VIII SMP Raudlatul Jannah. Pada gambar tersebut diketahui bahwa level literasi sains siswa Indonesia dalam PISA 2013 adalah berada pada below level 1 sampai level 4 dengan persentase pencapaian level tertingginya berada pada level 1. Sedangkan level literasi sains siswa kelas VIII-H SMP Muhammadiyah 5 Pucang Surabaya adalah berada pada level 2 sampai level 4 dengan persentase pencapaian level tertingginya berada pada level 3. Dan level literasi sains siswa kelas VIII SMP Raudlatul
Jannah adalah berada pada level 1 sampai level 5 dengan persentase pencapaian level tertingginya berada pada level 4.

Data hasil tes literasi sains siswa yang meliputi penguasaan domain sikap sains disajikan dalam Tabel 5.

Tabel 5 Penguasaan Domain Sikap Siswa

\begin{tabular}{|c|c|c|c|c|}
\hline \multirow{2}{*}{$\begin{array}{c}\text { Pernyataan } \\
\text { ke- }\end{array}$} & Persentase & Kategori & Persentase & Kategori \\
& $\mathbf{U 1}$ & U2 & \\
\hline 1 & 68,6 & Baik & 93,3 & $\begin{array}{c}\text { Sangat } \\
\text { Baik }\end{array}$ \\
\hline 2 & 79,0 & Baik & 92,4 & $\begin{array}{c}\text { Sangat } \\
\text { Baik }\end{array}$ \\
\hline 3 & 54,3 & Cukup & 94,3 & $\begin{array}{c}\text { Sangat } \\
\text { Baik }\end{array}$ \\
\hline 4 & 76,2 & Baik & 94,3 & $\begin{array}{c}\text { Sangat } \\
\text { Baik }\end{array}$ \\
\hline 5 & 65,7 & Baik & 86,7 & $\begin{array}{c}\text { Sangat } \\
\text { Baik }\end{array}$ \\
\hline 6 & 63,8 & Baik & 90,5 & $\begin{array}{c}\text { Sangat } \\
\text { Baik }\end{array}$ \\
\hline 7 & 62,9 & Baik & 94,3 & $\begin{array}{c}\text { Sangat } \\
\text { Baik }\end{array}$ \\
\hline 8 & 60,0 & Cukup & 91,4 & $\begin{array}{c}\text { Sangat } \\
\text { Baik }\end{array}$ \\
\hline 9 & 56,2 & Cukup & 92,4 & $\begin{array}{c}\text { Sangat } \\
\text { Baik }\end{array}$ \\
\hline 10 & 77,1 & Baik & 91,4 & $\begin{array}{c}\text { Sangat } \\
\text { Baik }\end{array}$ \\
\hline Rata-rata & 66,4 & Baik & 92,1 & $\begin{array}{c}\text { Sangat } \\
\text { Baik }\end{array}$ \\
\hline
\end{tabular}

Hasil tes literasi sains siswa khususnya pada domain sikap sains yang ditampilkan pada Tabel 5 dan 4.10 menunjukkan bahwa sikap sains siswa mengalami peningkatan antara sebelum dan sesudah kegiatan pembelajaran, yaitu dari kategori baik menjadi kategori sangat baik. Besarnya peningkatan rata-rata persentase nilai siswa adalah $25,7 \%$.

Berdasarkan hasil yang diperoleh, dapat diketahui bahwa kemampuan literasi sains siswa pada tahap implementasi mengalami peningkatan apabila dibandingkan dengan level literasi sains siswa pada tahap uji coba I. Peningkatan kemampuan literasi sains siswa pada tahap ini dipengaruhi oleh beberapa faktor, yaitu: (1) perangkat yang digunakan merupakan perangkat yang sudah valid dan merupakan perbaikan dari perangkat sebelumnya yang didasarkan pada saran para pakar serta hasil evaluasi pada uji coba I, (2) tingginya rata-rata keterlaksanaan pembelajaran yaitu sebesar 3,6 dengan kategori sangat baik yang mencerminkan kesesuaian antara RPP yang dikembangkan dengan kegiatan pembelajaran yang dilaksanakan, (3) selama proses pembelajaran berlangsung, aktivitas dominan yang dilakukan siswa adalah berlatih keterampilan proses sains dengan persentase 19,04\%. Pada aktivitas tersebut, siswa berlatih menggunakan metode ilmiah untuk memecahkan masalah yang mereka hadapi serta untuk mendapatkan pengetahuan dan konsep-konsep dari permasalahan yang diberikan, dan (4) Siswa antusias dalam mengikuti kegiatan pembelajaran yang ditunjukkan dengan respon positif yang diberikan siswa.

Kegiatan pembelajaran dilakukan dengan memadukan fase-fase metode guided discovery dengan kegiatan yang mampu melatih literasi sains siswa. Hal tersebut nampak pada perangkat yang dikembangkan, 
misalnya dengan mengeksplor kosa kata baru, membuat forum diskusi dan tanya jawab melalui inkuiry, menyediakan kesempatan untuk membaca teks bacaan, menggunakan strategi pre-reading (melihat gambar, menggarisbawahi, mendiskusi pengetahuan utama dan tujuan dari bacaan), dan merangkum. Adapun materi yang diajarkan, disajikan dengan menggunakan fenomena-fenomena yang dekat dengan dunia siswa. Dengan demikian, siswa dapat memahami dan mengaplikasikan pengetahuan yang mereka dapatkan dalam menyelesaikan masala-masalah atau menjawab pertanyaan-pertanyaan yang mereka jumpai dalam kehidupan.

Bruner (1966) menyatakan bahwa mengajar lebih dari untuk menghasilkan perpustakaan kecil. Akan tetapi, lebih dari itu yaitu mampu menjadikan peserta didik mampu berpikir bagi dirinya sendiri agar dapat mempertimbangkan, menjadi bagian dari proses membangun pengetahuan. Karena mengetahui merupakan proses dan bukan produk" (Nur, 2008: 10).

Discovery learning memiliki banyak manfaat diantaranya adalah mampu menggugah rasa keingintahuan peserta didik, mendorong untuk terus bekerja dalam menemukan jawaban, melatih keterampilan menyelesaikan masalah (problem solving) dan berpikir kritis secara mandiri karena pada pembelajaran ini mereka dituntut untuk melakukan analisis dan rekayasa terhadap informasi (Berlyne, 1965 dalam Nur, 2008: 11).

Sains yang didasarkan pada penemuan, melibatkan siswa dalam menggunakan ilmu pengetahuan sebagai alat untuk menjawab pertanyaan tentang fenomena dunia nyata. Jenis pertanyaan yang muncul merupakan upaya kolektif di mana siswa membandingkan pemikiran mereka dengan pemikiran orang lain, secara aktif berkomunikasi dengan satu sama lain, dan mengekspresikan ide-ide mereka melalui kata-kata dan tulisan. Pembelajaran melalui penemuan dan literasi nampak ketika siswa menggunakan ketrampilan membaca, menulis, dan bahasa lisan untuk menjawab pertanyaan tentang isi sains dan untuk membangun kapasitas mereka untuk terlibat dalam penalaran ilmiah (Hapgood dan Palincsar, 2006: 56).

Alfieri, dkk (2011) telah melakukan penelitian yang berjudul Does Discovery-Based Instruction Enhance Learning. Tujuan dari penelitian yang mereka lakukan adalah untuk mengetahui dampak dari pembelajaran penemuan tanpa bantuan dengan yang diberi bantuan secara eksplisit dan untuk mengetahui dampak dari pembelajaran penemuan yang diberi bantuan dengan pembelajaran penemuan yang diberi bantuan dengan cara lain (misalnya: secara eksplisit atau tanpa diberi bantuan). Dari penelitian yang telah dilakukan diketahui bahwa pembelajaran penemuan tanpa bantuan tidak memberikan keuntungan kepada siswa, pemberian umpan balik, bekerja dengan contoh, scaffolding, dan penjelasan prosedur yang harus dilakukan.

Hal tersebut didukung oleh penelitian Melani, Harlita, dan Sugiharto dalam penelitiannya yang berjudul Pengaruh Metode Guided Discovery Learning terhadap Sikap Ilmiah dan Hasil Belajar Kognitif Biologi Siswa
SMA Negeri 7 Surakarta Tahun Pelajaran 2011/2012, yang menyatakan bahwa metode guided discovery learning berpengaruh nyata terhadap sikap ilmiah dan hasil belajar kognitif biologi siswa SMA Negeri 7 Surakarta tahun pelajaran 2011/2012. Instrumen yang digunakan dalam penelitian yaitu angket untuk mengukur sikap ilmiah siswa dan soal untuk mengukur hasil belajar kognitif.

Turpin dan Cage (2004), telah melakukan penelitian dengan judul The Effects of an Integrated, Activity-Based Science Curriculum on Student Achievement, Science Process Skills, and Science Attitudes. Dalam penelitian tersebut, mereka membandingkan prestasi belajar, keterampilan proses sains, dan sikap ilmiah antara siswa yang diberikan program kurikulum sains terpadu dengan siswa yang diberikan program kurikulum tradisional. Dari penelitian yang telah dilakukan diketahui bahwa para peserta dalam penelitian yang diberi perlakuan dengan program kurikulum sains terpadu memiliki skor signifikan lebih tinggi di bidang ilmu pengetahuan dan keterampilan proses sains apabila dibandingkan dengan siswa yang menggunakan kurikulum tradisional. Sedangkan sikap sains, dalam program sains terpadu tidak menunjukkan perbaikan dibandingkan dengan grup kontrol.

\section{Respon Siswa}

Respon siswa merupakan pendapat siswa terhadap ketertarikan, perasaan senang dan keterkinian, serta kemudahan memahami komponen-komponen yang meliputi: materi/isi pelajaran, format materi ajar, gambargambar, kegiatan dalam LKS, suasana belajar, cara guru mengajar, dan metode pembelajaran yang digunakan. Respon siswa secara keseluruhan dapat dilihat dalam Tabel 6.

Data angket respon siswa dipaparkan dalam Tabel 6. Hasl analisis pada tabel tersebut menunjukkan bahwa respon siswa terhadap pembelajaran dengan menggunakan perangkat yang dikembangkan sangat baik. Kondisi inilah yang membuat siswa antusias dalam mengikuti pembelajaran. Data pada tabel tersebut diperoleh bahwa pendapat siswa terhadap kegiatan pembelajaran menunjukkan bahwa siswa cenderung memberi respon positif.

Dari tabel tersebut dapat diketahui bahwa siswa berpendapat tertarik pada komponen pembelajaran dengan persentase 99,2\% dan mengatakan baru dengan persentase $89,0 \%$ terhadap komponen kegiatan pembelajaran yang meliputi materi/isi pelajaran, format buku siswa, LKS, latihan keterampilan proses, suasana belajar, dan cara mengajar guru. Hal tersebut dikarenakan selama ini siswa jarang sekali mendapatkan pembelajaran dengan menggunakan metode guided discovery, sehingga sebagian besar siswa menyatakan senang dan baru terhadap kegiatan pembelajaran.

Tabel 6 juga memberikan informasi bahwa 92,2\% siswa merasa mudah dalam memahami Bahasa buku, materi/isi buku, contoh soal, LKS, dan cara guru mengajar. Siswa juga berminat $95,0 \%$ untuk mengikuti pembelajaran dengan model yang sama. Terkait soal-soal literasi sains, 95,2\% siswa menyatakan merasa baru 
terhadap butir-butir soal literasi sains dan $90,5 \%$ siswa menyatakan mudah dalam menjawab soal-soal tersebut. Selain itu, 93,6\% siswa merasa baru terhadap komponen keterampilan sains yang diajarkan, 91,4\% siswa merasa mudah dan $93,1 \%$ siswa mengerti dengan jelas terhadap keterampilan-keterampilan proses yang diajarkan.

Tabel 6 Angket Respon Siswa terhadap Kegiatan Pembelajaran

\begin{tabular}{|c|c|c|}
\hline Uraian Pertanyaan & \multicolumn{2}{|c|}{$\begin{array}{c}\text { Persentase Penilaian/Pendapat } \\
(\%)\end{array}$} \\
\hline $\begin{array}{l}\text { Bagaimanakah pendapat Anda } \\
\text { terhadap komponen } \\
\text { pembelajaran? }\end{array}$ & $\begin{array}{c}99,2 \\
\text { (tertarik) }\end{array}$ & $\begin{array}{c}0,8 \\
\text { (tidak tertarik) }\end{array}$ \\
\hline $\begin{array}{l}\text { Apakah anda merasa baru } \\
\text { terhadap komponen-komponen } \\
\text { pembelajara? }\end{array}$ & $\begin{array}{l}89,0 \\
\text { (baru) }\end{array}$ & $\begin{array}{c}11,0 \\
\text { (tidak baru) }\end{array}$ \\
\hline $\begin{array}{l}\text { Apakah Anda dapat dengan } \\
\text { mudah memahami komponen- } \\
\text { komponen pembelajaran? }\end{array}$ & $\begin{array}{c}92,2 \\
\text { (mudah) }\end{array}$ & $\begin{array}{c}7,8 \\
\text { (sulit) }\end{array}$ \\
\hline $\begin{array}{l}\text { Apakah Anda merasa baru } \\
\text { terhadap komponen-komponen } \\
\text { keterampilan proses yang } \\
\text { dilatihkan? }\end{array}$ & $\begin{array}{l}93,6 \\
\text { (baru) }\end{array}$ & $\begin{array}{c}6,4 \\
\text { (tidak baru) }\end{array}$ \\
\hline $\begin{array}{l}\text { Apakah Anda dapat mengikuti } \\
\text { dengan mudah komponen- } \\
\text { komponen keterampilan proses } \\
\text { yang dilatihkan? }\end{array}$ & $\begin{array}{l}91,4 \\
\text { (mudah) }\end{array}$ & $\begin{array}{l}8,6 \\
\text { (sulit) }\end{array}$ \\
\hline $\begin{array}{l}\text { Apakah Anda mengerti dengan } \\
\text { jelas terhadap komponen- } \\
\text { kompon keterampilan proses } \\
\text { yang dilatihkan? }\end{array}$ & $\begin{array}{l}93,1 \\
\text { (jelas) }\end{array}$ & $\begin{array}{c}6,9 \\
\text { (tidak jelas) }\end{array}$ \\
\hline $\begin{array}{l}\text { Bagaimanakah minat Anda, jika } \\
\text { pembelajaran } \\
\text { berikutnya/konsep yang lain } \\
\text { menggunakan pembelajaran } \\
\text { seperti ini? }\end{array}$ & \multirow{2}{*}{$\begin{array}{l}95,00 \\
\text { (berminat) }\end{array}$} & \multirow{2}{*}{$\begin{array}{l}5,00 \\
\text { (tidak } \\
\text { berminat) }\end{array}$} \\
\hline $\begin{array}{l}\text { Bagaimanakah minat Anda, jika } \\
\text { semua pokok bahasan/konsep } \\
\text { diajarkan dengan menggunakan } \\
\text { pembelajaran seperti ini? }\end{array}$ & & \\
\hline $\begin{array}{l}\text { Bagaimanakah penjelasan guru } \\
\text { pada saat kegiatan belajar } \\
\text { mengajar? }\end{array}$ & \multirow[b]{2}{*}{$\begin{array}{l}90,5 \\
\text { (jelas) }\end{array}$} & \multirow[b]{2}{*}{$\begin{array}{c}9,5 \\
\text { (tidak jelas) }\end{array}$} \\
\hline $\begin{array}{l}\text { Bagaimana bimbingan yang } \\
\text { diberikan guru pada saat } \\
\text { mengerjakan LKS selama } \\
\text { kegiatan belajar mengajar } \\
\text { berlangsung? }\end{array}$ & & \\
\hline $\begin{array}{l}\text { Apakah Anda merasa mudah } \\
\text { untuk menjawab butir soal-soal } \\
\text { literasi sains? }\end{array}$ & \multirow{2}{*}{$\begin{array}{l}92,9 \\
\text { (baru) }\end{array}$} & \multirow{2}{*}{$\begin{array}{c}7,2 \\
\text { (tidak baru) }\end{array}$} \\
\hline $\begin{array}{l}\text { Apakah Anda merasa baru } \\
\text { terhadap butir soal-soal literasi } \\
\text { sains? }\end{array}$ & & \\
\hline
\end{tabular}

Hal tersebut sesuai dengan prinsip-prinsip Piaget dalam kegiatan pembelajaran yaitu keterlibatan siswa secara aktif dalam pembelajaran. Agar siswa dapat terlibat secara aktif dalam pembelajaran, kegiatan pembelajaran hendaklah dapat menarik minat dan meningkatkan pemahaman siswa. Untuk menarik minat dan meningkatkan pemahaman siswa dalam belajar, guru perlu mengaitkan pengetahuan baru dengan struktur kognitif yang telah dimiliki oleh siswa. Materi pelajaran perlu disusun dengan menggunakan pola tertentu, yaitu dari materi sederhana menuju ke materi kompleks. Hal yang tidak boleh dilalaikan adalah perbedaan individual yang dimiliki oleh masing-masing siswa yang harus diperhatikan, karena hal ini merupakan faktor yang sangat penting dalam mempengaruhi keberhasilan siswa.

Sejalan dengan teori tersebut, Balim (2009) menyatakan bahwa pembelajaran discovery menunjukkan keaktifan dan keterampilan siswa dalam proses penyelidikan serta siswa lebih efektif dalam membangun pengetahuan mereka sendiri. Dari hal tersebut menunjukkan bahwa siswa memberikan respon positif dalam kegiatan pembelajaran dengan menggunakan pembelajaran discovery, sehingga siswa aktif dan terampil dalam kegiatan pembelajaran.

\section{PENUTUP}

\section{Temuan Hasil Analisis Data}

Berdasarkan penelitian yang telah dilakukan dengan menggunakan perangkat pembelajaran IPA berbasis Kurikulum 2013 untuk melatih literasi sains siswa, diperoleh temuan sebagai berikut: (1) Ditinjau dari segi validitas, komponen perangkat pembelajaran adalah valid, memiliki tingkat keterbacaan sebesar $80 \%$, dan tingkat kesulitan yang rendah yaitu 10,6\%. (2) Perangkat pembelajaran yang dihasilkan praktis digunakan dalam pembelajaran yang terlihat dari tingginya keterlaksanaan pembelajaran dengan skor rata-rata kesuluruhan keterlaksanaan pembelajaran adalah 3,6 dengan kategori sangat baik. (3) Perangkat pembelajaran yang dikembangkan juga efektif untuk melatih kemampuan literasi sains siswa sampai pada level 4. Selain itu, aktivitas siswa dominan aktif dalam pembelajaran, siswa juga memberikan respon positif terhadap kegiatan pembelajaran.

\section{Simpulan}

Berdasarkan hasil analisis data, dapat disimpulkan bahwa perangkat pembelajaran IPA berbasis Kurikulum 2013 materi tekanan zat cair dan penerapannya dalam kehidupan sehari-hari layak digunakan untuk melatih literasi sains siswa SMP kelas VIII.

\section{Saran}

Berdasarkan hasil penelitian dan pembahasan yang telah dilakukan, peneliti menyarankan beberapa hal berikut: (1) Pengembangan perangkat pembelajaran yang dilakukan oleh seorang peneliti harus benar-benar valid, praktis, dan efektif. (2) Dalam kegiatan pembelajaran dengan metode guided discovery, guru perlu memotivasi siswa untuk melakukan penyelidikan sendiri yang terstruktur dalam menemukan konsep-konsep baru yang berkaitan dengan materi yang dipelajari. (3) Alokasi waktu harus diatur dan digunakan dengan tepat untuk dapat mencapai hasil yang maksimum.

\section{DAFTAR PUSTAKA}

Akinbola, A.O.and Afolabi, F. (2009). "Constructivist Practices Through Guided Discovery Approach: The Effect on Students Cognitive Achievments in Nigeria Senior Seconder School Phisics". Bulgarian 
Journal of Science and Education Policy (BJESP). Vol.3 No.2, pp.233-252.

Alfieri, Brooks, Aldrich, and Tenenbaum. (2011). "Does Discovery-Based Instruction Enhance Learning". Journal of Educational Psychology. Vol. 103, No.1, $1-18$.

Badan Standar Nasional Pendidikan. (2006). Penilaian Buku Teks Pelajaran IPA SMP/MTs. Jakarta: Badan Standar Nasional Pendidikan (BSNP).

Balim, A.G. (2009). "The Effect of Discovery Learning on Student Success and Inqury Learning Skills". Journal of Educational Research. Vol.35, pp.1-20.

Borich, G. D. (1994). Observation Skills for Effective Teaching. USA: Macmilan Publishing Company.

Charin, A. (1993). Teaching Science Through Discovery Seventh Edition. New York: Mcmillan Publishing Company.

Dick, W. and Lou, C. (1990). The Systematic Design of Instruction. Florida State: Haper Collins Publisher.

Fathur Rohim, Hadi Susanto, Ellianawati. (2012). "Penerapan Model Discovery Terbimbing pada Pembelajaran Fisika untuk Meningkatkan Kemampuan Berpikir Kreatif'. Unnes Physics Education Journal. Vol. 1 No. 1 pp. 1-5.

Hapgood,S. dan Palincsar, A.S. (2006). "Where Literacy and Science Intersect". ASCD. Vol. 64, number 4.

Ibrahim, Muslimin. (2010). Dasar-dasar Proses Belajar Mengajar. Surabaya: Unesa: University Press.

Nur, M. (2008). Pengajaran Berpusat kepada Siswa dan Pendekatan Konstruktivis dalam Pengajaran (Edisi 5). Surabaya: PSMS UNESA.

OECD. (2000). Sample Tasks from the PISA 2000 Assessment. Reading, Mathematical, and Scientific Literacy. (11 November 2013).

OECD. (2013). PISA 2012 Assessment and Analytical Framework: Mathematics, Reading, Science, Problem Solving and Financial Literacy. http://dx.doi.org/10.1787/9789264091450-en Oktober 2013).
OECD. (2013). PISA 2012 Results: What Students Know and Can Do Student Performance in Mathematics, Reading and Science Volume I. http://dx.doi.org/10.1787/9789264201118-en (15 Januari 2014).

Sitepu, B.P. (2010). Keterbacaan (http://bintang sitepu Wordpress. Com/2009/09/11/keterbacaan/).

Subali, B., Effendy, Suyono, Raharjo, Wasis, dan Sudibyo, E. (2009). Panduan Pengembangan Model Pembelajaran IPA Terpadu. Departemen pendidikan nasional.

Turpin, T. dan Cage, B.N. (2004). The Effects of an Integrated, Activity-Based Science Curriculum on Student Achievement, Science Process Skills, and Science Attitudes". Electronic Journal of Literacy through Science, Vol. 3, 2004.

Ibrahim, Muslimin. (2014). "Inovasi Pendidikan Sains dalam Implementasi Kurikulum 2013”. Makalah yang disampaikan pada Seminar Pendidikan Sains di PPs Unesa tanggal 18 Januari 2014.

Inzanah. (2014). Pengembangan Perangkat Pembelajaran IPA berbasis Kurikulum 2013 untuk Melatih Literasi Sains Siswa SMP (Makalah komprehensif tidak dipublikasikan). Universitas Negeri Surabaya.

Kementerian Pendidikan dan Kebudayaan. (2013). Materi Pelatihan Guru Implementasi Kurikulum 2013. SMP/MTs Ilmu Pengetahuan Alam. Kementerian Pendidilan dan Kebudayaan.

Melani, R., Harlita, dan Sugiharto, B. (2012). "Pengaruh Metode Guided Discovery Learning terhadap Sikap Ilmiah dan Hasil Belajar Kognitif Biologi Siswa SMA Negeri 7 Surakarta Tahun Pelajaran 2011/2012”. Jurnal Pendidikan Biologi. Vol. 4, Nomor1, Halaman 97-105.

NCES. (2012). Highlights From PIRLS 2011 Reading Achievement of U.S. Fourth-Grade Students in an International Context. U.S. Department of Education. 